\title{
Protective effects of zinc on oxidative stress enzymes in liver of protein
} deficient rats

\author{
P. Sidhu, M. L. Garg and D. K. Dhawan* \\ *Department of Biophysics Panjab University Chandigarh. India
}

\begin{abstract}
This study was designed to evaluate the protective effects of zinc on the liver activities of antioxidant enzymes in protein-deficient rats. Zinc sulfate at a dose level of $227 \mathrm{mg} / \mathrm{l}$ in drinking water was administrated to Sprague Dawley normal control as well as to protein-deficient rats for a total duration of eight weeks. The effects of zinc treatment and protein deficiency alone as well as combined were studied on rat liver antioxidant enzymes which included catalase, glutathione peroxidase (GPX), glutathione reductase (GR), superoxide dismutase (SOD), and glutathione S-transferase (GST). Protein deficiency in normal rats resulted in a significant increase in hepatic lipid peroxidation and in catalase, Gpx, GR and GST activity. A significant inhibition in the levels of SOD activity and reduced glutathione (GSH) was observed following protein deficiency in normal rats. Zn treatment to protein deficient animals lowered lipid peroxidation and catalase, Gpx and GST activities, and also resulted in a significant elevation in the levels of GSH and SOD activity. The concentration of zinc decreased significantly in protein deficient animals but returned to normal levels when zinc was administered.
\end{abstract}

(Nutr Hosp 2004, 19:341-347)

Key words: Zinc. Protein deficiency. Liver antioxidants.

\section{Introduction}

Nutritional stress in the form of deficient protein condition is quite prevalent in the developing coun-

Correspondence: P. Sidhu

Department of Biophysics

Panjab University

Chandigarh

160014 India

E-mail: pardeepsidhu@yahoo.co.uk

Recibido: 30-VII-2004.

Aceptado: 11-VIII-2004.

\author{
EFECTOS DEL ZINC SOBRE ENZIMAS DE \\ ESTRÉS OXIDATIVO EN EL HÍGADO DE RATAS \\ CON DÉFICIT PROTEICO
}

\section{Resumen}

Este estudio fue diseñado para estudiar los efectos protectores del zinc sobre la actividad de los enzimas antioxidantes del hígado en ratas con déficit proteico. Se administró sulfato de zinc en una dosis de $227 \mathrm{mg}$ por litro en agua a ratas Sprage Dawley control y a un grupo de ratas con déficit proteico durante un período de ocho semanas. Los efectos del tratamiento de zinc y de la deficiencia proteica per se, así como su combinación, fueron estudiados sobre los encimas antioxidantes de $i$ hígado de la rata, incluyendo catalasa, glutation peroxidasa (GPX), glutation reductasa (GR), superóxido dismutasa (SOD) y glutation s-transferasa (GST). La deficiencia protéica en ratas normales produjo un aumento significativo en la peroxidación lipídica del hígado, así como en la actividad de catalasa GPX, GR y GST. Hubo una inhibición significativa de los niveles de actividad SOD y una reducción del glutation en las ratas con déficit proteico. El tratamiento con zinc a los animales con déficit proteico disminuyó la peroxidación lipídica y la actividad de catalasa GPX y GST, y también produjo una elevación significativa en los niveles de actividad de GSH y SOD. La concentración de zinc disminuyó de manera significativa en los animales con déficit proteico, pero volvió a los niveles normales cuando se administró zinc.

(Nutr Hosp 2004, 19:341-347)

Palabras clave: Zinc. Déficit proteico. Antioxidantes hepáticos.

tries, including Asian countries in which $33 \%$ of the world population lives ${ }^{1}$. Even in developed countries like America up to $85 \%$ of the older adults living in nation's nursing homes suffer from protein-caloric malnutrition $(\mathrm{PCM})^{2}$. Protein deficiency is rampant among the industrial workers in India and other third world countries ${ }^{3}$ and this may be associated with adverse functional disorders of body metabolism, which is likely to be exaggerated in conditions of heavy metal toxicity. Protein malnutrition disorders include growth failure, hypoproteoinemia, hypoalbuminemia, 
edema, fatty liver, atrophy of lymphoid tissues and decreased host immune defense in humans and animals ${ }^{4,5}$. Protein deficient diet intake strongly influences the activity of drug metabolizing enzymes ${ }^{6,7}$ as well as antioxidant enzymes ${ }^{8,9}$. Feeding of a protein-deficient diet to rats has been shown to increase Hpid peroxidation (LPO) and to induce significant changes in the liver activities of catalase, glutathione peroxidase (GPX) and superoxide dismutase (SOD) in the liver ${ }^{10,11}$. The significant increase in SOD activity associated with the decrease in plasma ceruloplasmin, antioxidant vitamins and the whole blood GPX activity in protein energy malnourished children suggest that these children are potentially susceptible to high oxidative stress. It has been proposed that free radicalmediated tissue damage may be involved in the pathogenesis of liver diseases, mainly because of the inadequate protective and repair mechanism in protein deficient individuals ${ }^{12}$.

Persons afflicted with protein malnutrition are deficient in a variety of micronutrients. Protein deficiency has been shown to decrease the hepatic levels of zinc, manganese, copper, calcium and magnesium in experimental animals ${ }^{13,14}$. Alterations in the levels of trace elements result in number of diseases like hypoalbuminemia, and anemia in malnourished children ${ }^{15}$. Bhaskaram and Hemalatha. $1995^{16}$ observed that children suffering from severe protein energy malnutrition have very low levels of the thymulin, hormone which is a sensitive indicator of zinc status in the body, and low leukocyte count, indicating zinc deficiency, which got improved when zinc supplements were provided along with rehabilitation diets. It is known that dietary protein variation affects the absorption and uptake of ${ }^{65} \mathrm{Zn}^{17}$. Zinc supplementation during nutritional rehabilitation of PEM hastens the recovery from protein deficiency and helps in gaining body weight ${ }^{18}$. Supplementation of zinc restores serum thymulin activity and improves the nutritional status of elderly people in terms of food intake and serum albumin ${ }^{19,20}$.

Zinc has been shown to have an antioxidant potential through the non-enzymatic stabilization of biomembranes and biostructures. Dhawan and Goel, $1994^{21}$ have shown that $\mathrm{CCI}_{4}$ induced lipid peroxidation in the microsomal fraction of liver homogenates was inhibited by adding zinc to the incubation medium. The present study was undertaken to further elucidate the protective role of zinc on the status of antioxidant enzymes in conditions of protein deficiency.

\section{Materials and methods}

\section{Animals}

Rats in the weight range of 110-120 g of Sprague Dawley (SD) strain were obtained from the Central Animal Home, Panjab University, Chandigarh. The animals were housed in polypropylene cages in the animal house of the Department of Biophysics, under hygienic conditions and were acclimatized for at least one week before putting them on different treatments. Thereafter, the animals were randomly divided into four groups each having ten animals each.

\section{G-1, Control}

Animals in this group served as normal controls and were fed a diet with a normal protein content (18\%). Composition of the $\operatorname{diet}^{22}$ is given in the table below.

\section{G-2, Protein deficient (PD)}

Protein deficiency was induced in the animals of this group by feeding a protein-deficient diet with a $8 \%$ protein content. Composition of the $\operatorname{diet}^{22}$ is also given in the table.

\section{G-3 Zinc treated (Zn)}

Animals were given zinc in the form of $\mathrm{ZnSO}_{4}$ at a dose level of $227 \mathrm{mg} / \mathrm{L}$ in drinking water and had free access to the normal diet.

\section{$\mathrm{G}-4, \mathrm{Zn}+\mathrm{PD}$ treated}

Animals received $\mathrm{ZnSO}_{4}$ in the drinking water and were given the protein deficient diet.

\begin{tabular}{lcc}
\hline $\begin{array}{l}\text { Composition } \\
(\%)\end{array}$ & $\begin{array}{c}\text { Normal (18\%) } \\
\text { Protein Diet }\end{array}$ & $\begin{array}{c}\text { Low (8\%) } \\
\text { Protein Diet }\end{array}$ \\
\hline Casein $(\mathrm{g})$ & 18 & 8 \\
Starch $(\mathrm{g})$ & 25 & 31.5 \\
Sucrose $(\mathrm{g})$ & 25 & 31.5 \\
Cellulose $(\mathrm{g})$ & 14 & \\
Corn oil $(\mathrm{ml})$ & 10 & 10 \\
Vitaminmixtura $(\mathrm{g})$ & 2 & 2 \\
Salt mixture $(\mathrm{g})$ & 6 & 6 \\
\hline
\end{tabular}

The treatments of rats continued for a period of eight weeks. At the end of the treatment, the animals were weighted and were sacrificed by exsanguination under light anesthesia. Livers were removed immediately and were perfused and rinsed in normal saline $(\mathrm{NaCl}, 9$ $\mathrm{g} / \mathrm{l} / \mathrm{w} / \mathrm{v})$. One lobe was preserved by for the determination of various trace elements and the other was processed immediately for various biochemical investigations.

\section{Biochemical determinations}

The livers were removed and perfused with normal saline $(0.9 \% \mathrm{WN})$ to reduce red blood cell contamination. Samples were homogenized in $100 \mathrm{mM}$ potassium phosphate buffer ( $\mathrm{pH} 7.5$ ) containing $0.15 \mathrm{M}$ 
$\mathrm{KCl}$ to obtain $25 \%$ homogenate, using a motor driven teflon fitted homogenizer. The homogenates were centrifuged in a cold centrifuge $\left(4^{\circ} \mathrm{C}\right.$, REMI instruments, Bombay) at $10,000 \mathrm{xg}$ for 30 minutes. The pellets were discarded and the supernatants were again centrifuged at $10,000 \mathrm{xg}$ for 30 minutes. The pellets were discarded and final post mitochondrial supernatant (PMS) was preserved for the estimation of antioxidant enzymes and lipid peroxidation.

The method of Luck, 1971 was used for the estimation of catalase ${ }^{24}$. Glutathione peroxidase was assayed by the method of Flohe and Gurtzler ${ }^{25}$. Glutathione reductase was assayed by the method of Williams and Arscott ${ }^{26}$. The activity of superoxide disminase was estimated by using the method which is based on the principle of the inhibitory effect of SOD on reduction of nitroblue tetrazolium (NBT) dye by superoxide anions, which are generated by the phomoxidation of hydroxzylamine hydrochloride $\left(\mathrm{NH}_{2} \mathrm{OH} . \mathrm{HCI}\right)$. Estimation of reduced glutathione was performed in the tissue homogenates of liver by the method of Moron et $\mathrm{al}^{27}$. Glutathionc-S-Transferase was assayed by the method of Habig et al ${ }^{28}$. Lipid peroxidation was estimated by the method of Ohokawa et al, $1979^{29}$. Protein was measured by the method of Lowry et al, $1951^{23}$.

\section{Zinc concentration}

Estimations of zinc concentrations in the liver samples of the different treatment groups were carried using Energy Depressive X-ray Fluorescence (EDXRF), one of the most suitable analytical method to analyze trace elements because of its properties such as non-destructive, sensitivity up to ppm and multielemental analysis.

The liver tissues of all the animals were oven dried at $70^{\circ} \mathrm{C}$ to a constant weight and then ground with the help of Agate Pestle and Mortar. 300 mg dried powder of the tissue so obtained was weighed and mixed with equivalent mount of Hoechst Wachs (wax) to make self supporting pellets. The pellets were made by using a specially designed pure, steel dye and a hydraulic press from Paul weber, Germany. A force of approximately $45 \mathrm{KN}$ (Kilo newtons) was applied at the dye top in order to make pellets of uniform thickness.

The pellets of tissues were analyzed using an EDXRF X-Lab, 2000 to determine the levels of various elements. The X-lab, 2000 spectrometer involved a $0.4 \mathrm{kw}$ Pd mode Xray tube as source of excitation. The power of the X-ray tube was adjusted on line for each individual measurement by the spectrophotometer software, to secure optimum acquisition parameters for the current analysis.

Presently, different X-ray energies and excitation modes are being used but the most important mode used was of $40 \mathrm{kV}$ and excitation used was polarized X-Ray. A Si (Li) detector coupled with computer (Pentium, $600 \mathrm{MH}$, software package SPECTRO X-
$\mathrm{LAB}^{\text {PRO }}$ 2.2) was used to collect the flourescent X-ray spectra from the samples. The X-ray tube, secondary exciter, target and the $\mathrm{Si}(\mathrm{Li})$ detector were placed in a triaxial geometry mode. This geometry was used to minimize the background due to scattered photons.

\section{Statistical analysis}

The statistical significance of the differences was measured by one way analysis of variance (ANOVA) followed by Newman-Keuls test. The determinations are presented as Mean + S.D.

\section{Results}

The results of all the experiments conducted during the current study we depicted in various tables. All the results of various treatment groups have been compared with their normal controls. Results of zinc + protein deficient (G-4) treated group have been computed with the results of the protein deficient group $(\mathrm{G}-2)$.

\section{Body weights}

Changes in the body weight of the animals subjected to the different treatments me shown in table I. Body weights of normal control and zinc treated rats, increased progressively throughout the study. Protein deficiency resulted in a significant $(\mathrm{p}<0.001)$ decrease in the body weights after eight weeks, when compared to normal control rats. Zinc treatment to the protein deficient rats tended to improve the body weight growth in comparison to protein deficient (G-2) rats but body weights in protein deficient rats were statistically different from normal control rats.

\section{Hepatic protein contents}

Table I shows hepatic protein contents in the different experimental groups expressed as $\mathrm{mg} \mathrm{g}^{-1}$ tissue. Protein deficient animals, showed a highly significant $(\mathrm{P}<0.001)$ reduction in the hepatic protein contents

\section{Table I}

Effect of zinc treatment on body weight and hepatic protein concentration in protein-deficient rats

\begin{tabular}{|c|c|c|}
\hline Group & Weight $(g)$ & $\begin{array}{c}\text { Hepatic Protein } \\
\text { (mg. } g^{-1} \text { tissue) }\end{array}$ \\
\hline G-1 Control & $199 \pm 7$ & $156 \pm 5$ \\
\hline G-2 Protein-deficient & $146 \pm 29^{a 3}$ & $112 \pm 5^{\mathrm{a} 3}$ \\
\hline G-3 Zinc-treated & $180 \pm 22$ & $162 \pm 7$ \\
\hline G-4 Protein-deficient + Zinc & $161 \pm 30^{\mathrm{al}}$ & $151 \pm 9^{\mathrm{b} 3}$ \\
\hline
\end{tabular}

Values me Mean \pm SD.

al $\mathrm{p}<0.05,{ }^{\mathrm{a} 2} \mathrm{p}<0.01$ and ${ }^{\mathrm{a}} \mathrm{p}<0.001$ in comparison to G-1.

${ }^{\mathrm{bl}} \mathrm{p}<0.05,{ }^{\mathrm{b} 2} \mathrm{p}<0.01$ and ${ }^{\mathrm{b3}} \mathrm{p}<0.001$ comparison of G-4 with G-2. 
as compared to the control group. However, zinc administration to the protein deficient rats helped in raising the hepatic protein contents as compared to their respective controls.

\section{Antioxidant enzymes and lipid peroxidation}

The effects of zinc treatment in control and protein deficient rats in different groups on hepatic lipid peroxidation, catalase, glutathione peroxidase, glutathione reductase, superoxide dismutase, reduced glutathione and glutathione-S-transferase areshown in table II.

Protein deficient rats showed a significant ( $\mathrm{p}<$ 0.001 ) increase in hepatic lipid peroxidation, catalase, glutathione peroxidase, glutathione reductase, and glutathione-S-transferase. A significant $(\mathrm{p}<0.001)$ inhibition in the levels of superoxide dismutase activity and reduced glutathione was detected following protein deficiency in normal rats.

$\mathrm{Zn}$ treatment to protein deficient animals could lower significantly $(\mathrm{p}<0.01)$ the already raised levels of lipid peroxidation and the activities of enzymes catalase, glutathione peroxidase and glutathione-Stransferase when compared to control animals. Also, $\mathrm{Zn}$ treatment to the protein deficient animals resulted in a significant elevation $(\mathrm{P}<0.001)$ in the levels of GSH and SOD activity as compared to their respective controls, thereby indicating its effectiveness in regulating their levels in adverse conditions.

\section{Hepatic concentration of zinc}

Table III shows the concentration of zinc in liver tissue of the different groups. Zinc concentration decreased significantly in protein-deficient animals. However zinc levels got elevated to within normal levels in these groups in which zinc was administrated along with other treatments.
Table III

Levels of zinc following zinc treatment in protein-deficient rats

\begin{tabular}{llc}
\hline & Group & Zinc $(\mu g / g)$ \\
\hline G-1 & Control & $58 \pm 6$ \\
G-2 & Protein-deficient & $40 \pm 5^{\mathrm{a} 3}$ \\
G-3 & Zinc-treated & $58 \pm 8$ \\
G-4 & Protein-deficient + Zinc & $51 \pm 5^{\mathrm{b} 2}$ \\
\hline
\end{tabular}

Values me Mean \pm SD.

${ }^{\mathrm{a}} \mathrm{p}<0.05$, ${ }^{2} \mathrm{p}<0.01$ and ${ }^{\mathrm{a} 3} \mathrm{p}<0.001$ in comparison to G-1.

${ }^{b l} \mathrm{p}<0.05,{ }^{\mathrm{b} 2} \mathrm{p}<0.01$ and ${ }^{\mathrm{b} 3} \mathrm{p}<0.001$ comparison of G-4 with G-2.

\section{Discussion}

We observed that the body weights of normal control and zinc treated rats increased progressively throughout the study. Protein deficiency resulted in a significant decline in the body weight after eight weeks, when compared to normal control rats. Loss in body weight is characteristic of protein malnutrition. In an earlier report from our laboratory it has been observed that protein deficiency leads to significant growth retardation in animals 11. Many other workers have also reported the decrease in body weight due to protein deficiency ${ }^{30,31}$. It has been observed in these studies that retardation in body weight growth over a period is not due to low food intake but to a deficiency in protein intake. Zinc treatment to the protein-deficient rats tended to improve the body weight growth. Similar protective effects of zinc in improving the body weight gain of the animals have also been reported in other studies, in which radiations or carbon tetrachloride was used to induce liver injury $^{21,32,33}$. The protective effects of zinc could be attributed to its ability to reduce collagen accumulation in liver and also it exerts critical physiological role in regulating the structure and function of cells.

\section{Table II}

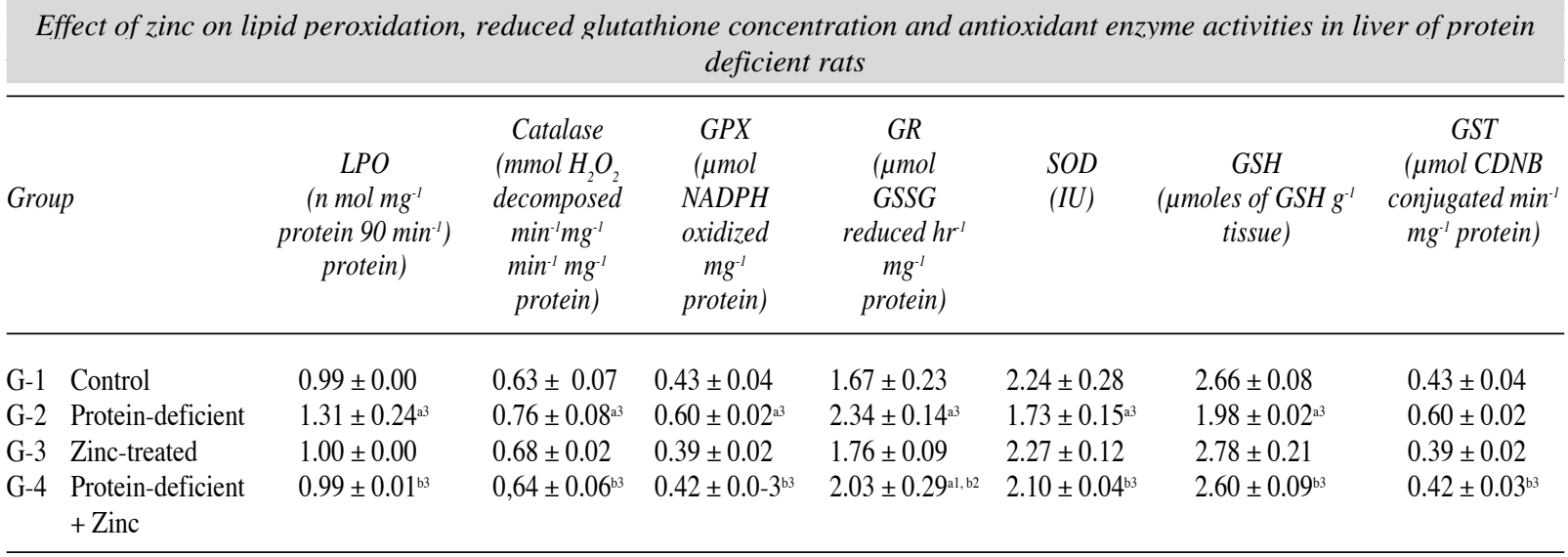

Values me Mean \pm SD.

${ }^{a 1} \mathrm{p}<0.05,{ }^{\mathrm{a} 2} \mathrm{p}<0.01$ and ${ }^{\mathrm{a} 3} \mathrm{p}<0.001$ in comparison to $\mathrm{G}-1$.

${ }^{\mathrm{b}} \mathrm{p}<0.05,{ }^{\mathrm{b} 2} \mathrm{p}<0.01$ and ${ }^{\mathrm{b} 3} \mathrm{p}<0.001$ comparison of G-4 with G-2. 
In our study, the levels of zinc decreased in proteindeficient rats, but returned to normal following zinc supplementation. The observation of depressed $\mathrm{Zn}$ levels in the liver of protein deficient rats in the present investigation we in conformity with previous studies $^{34,13}$. Abnormalities in zinc metabolism leading to its deficiency are generally attributed to various factors like, malabsorption, malnutrition, decreased intestinal zinc binding factors or the increased excretion of the zinc via the gastrointestinal tract or via urine are of common occurrence in chronic liver disorders ${ }^{35}$. The results of the current study for lowered zinc concentrations could be explained on the basis that either it is excessively being utilized in providing antioxidant defense mechanism or there is some defect in the absorption/ metabolism of zinc in toxic conditions created by protein deficiency. Studies carried out in animals and humans had shown that zinc is essential for utilization of aminoacids ${ }^{36}$. Conversely, protein malnutrition plays a major role on liver zinc depletion $^{34}$. Zinc has been found to be associated with metal binding proteins that are known to regulate the functions of zinc as well as copper. Metallothionein also plays a role in the detoxification of heavy metals and stabilize membranes ${ }^{37}$.

Protein-deficient treatment groups, showed a highly significant reduction in the protein content as compared to normal control group which is in agreement with the earlier reports ${ }^{38}$. Davenport et al, $1994^{38}$ demonstrated that in protein deficient states, the reduction in serum albumin contents were due to depletion in amino acid precursors of albumin synthesis. However, zinc administration to the protein deficient rats helped in raising the hepatic protein contents $(\mathrm{p}<$ 0.001 ) and were brought to normal limits as compared to their respective controls. This property of $\mathrm{Zn}$ could be attributed to its role in the induction of metallothionein ( $\mathrm{Zn}$ binding protein) thereby regulating the amino acid precursors for albumin synthesis ${ }^{39,40}$.

Lipid peroxidation is the process of oxidative degradation of polyunsaturated fatty acids (PUFA). Its occurrence in biological membranes causes impaired membrane function, impaired structural integrity ${ }^{41}$, decrease in fluidity, and inactivation of a number of membrane bound enzymes and protein receptors. Lipid peroxidation is an autocatalytic free-radical process and could be responsible for DNA damage ${ }^{42}$.

A significant increase in malondialdehyde products was observed in the protein deficient groups in the present study which suggested that low protein diet intake might result in enhanced lipid peroxidation in liver. These results seems to be in agreement with previous findings ${ }^{8,11}$ suggesting that the rats fed on a low protein diet might be more susceptible to peroxidative tissue damage under the influence of oxidative stress. The increased lipo peroxidation could be attributed to the reduction in detoxifying hyperperoxides in protein deficient conditions. Moreover, the degree of depressions of detoxifying hyperperoxides in protein defi- cient conditions might also be correlated with the degree of protein deficiency ${ }^{8}$.

The normalization of lipo peroxidation due to $\mathrm{Zn}$ administration could be attributed to its antiperoxidative property. Studies have shown that $\mathrm{Zn}$ causes inhibition of both endogenous as well as induced lipid peroxidation to stabilize biomembranes ${ }^{43,18}$. Further, the levels of zinc which were reduced in low protein conditions got maintained by its supplementationand this apparently contributed to a reduction in lipid peroxidation.

To protect themselves against free radicals, cells have developed antioxidant defenses and repair systems which prevent the accumulation of oxidatively damaged molecules. The antioxidant defense system include enzymes like glutathione peroxidase (GPx), catalase, glutathione reductase (GR), glutathione-stransferase (GST), superoxide dismutase (SOD), as well as small molecules such as ascorbic acid, reduced glutathione (GSH) and uric acid ${ }^{44,45}$. Catalase is a ubiquitous enzyme and is a major component in primary antioxidant enzyme system, which catalyzes the decomposition of $\mathrm{H}_{2} \mathrm{O}_{2}$ to $\mathrm{H}_{2} \mathrm{O}$ and sharing this function with glutathione peroxidase (GPx). Glutathione peroxidase on the other hand is located in the cytosol and mitochondrial matrix and catalyzes the reduction of $\mathrm{H}_{2} \mathrm{O}_{2}$ and lipid and nonlipid hydroperoxides to oxidized glutathione (GSSG) using two molecules of GSH. Further oxidized, GSSG is reduced back to GSH by glutathione reductase (GR), which utilizes NADPH regenerated by glucose-6-phosphate dehydrogenase.

In the present study, after subjecting the rats to protein deficiency the hepatic activity of catalase, glutathione peroxidase and glutathione reductase got raised but superoxide dismutase activity was found to be inhibited. Darmon et al, $1993^{10}$ also observed an increase in catalase activity in low protein diet fed rats. Zhu et al, $1993^{46}$ accounted the high levels of GPx following protein deficiency due to its low utilization and increase in synthesis. An enhanced level of glutirthione reductase has been reported earlier in rats fed protein restricted diet ${ }^{47,48}$. The observed elevation in the activities of both GPx and GR in the present study under low protein diet may be due to enhanced synthesis of these enzymes, which are actively involved in reducing the $\mathrm{H}_{2} \mathrm{O}_{2}$ generation ${ }^{49}$.

The observed increase in lipid peroxidation in the protein deficient group seems to be associated with a decrease in SOD activity, as SOD inhibits hydrogen peroxide by scavenging free oxide molecule ${ }^{50}$. Our results regarding the significant decrease of SOD following restriction of protein diet are in agreement with earlier reports ${ }^{48,51}$. Following zinc treatment the altered levels of enzymes tended to be normalized because of the antioxidant property of zinc.

Glutathione-s-transferases (GSTs) form a group of enzymes that are present in high concentrations in the cytosol and catalyze a wide variety of substitution reactions in which glutathione (GSH) replaces an easily dis- 
placed group on the xenobiotic, and thus prevents the subsequent toxic reactions ${ }^{52}$. This reaction involves a compound with an electrophilic atom and GST facilitates the nucleophilic attack of glutathione thiolate on this electron deficient atom of the hydrophobic compound. GSH plays an important role in intracellular protection against toxic compounds, reactive oxygen species, and free radicals ${ }^{53}$. Reduced glutathione $(\mathrm{GSH})$ protects the liver microsomes against the effects of reactive (peroxides and oxygen) intermediates which are formed by $\mathrm{Cy}$ tochrome P450 system as well as lipid peroxidation ${ }^{54}$.

In the present study the low protein diet caused a marked decrease in the levels of GSH which is in agreement with earlier studies ${ }^{47,55}$. Ayala et al $^{47}$ observed that in rats fed on a low protein diet, supplemented with all essential amino acids except methionine, there was a decrease of GSH levels. They proposed that low intracellular concentration of cysteine available for GSH synthesis and feed back inhibition of gamma glutamyl cysteine synthetase may be responsible for inhibition in the activities under protein deficient conditions. The low protein diet results in increase of hepatic levels of glutathione degrading enzyme, gamma glutamyl transferase $(\gamma-\mathrm{GT})$ and, thus, a decreased concentration of glutathione ${ }^{56}$. Because GSH is an important component of the detoxification mechanism, its lowered concentration in protein-deficient conditions would, therefore, lead to decreased detoxification capacity of liver. Further reduction in GSH levels in protein deficient is understandable in the light of elevation of GPx under these conditions. The present observations of a decline in GSH levels in protein deficient groups are in coherence with earlier reports ${ }^{11}$ and can be attributed to the activation of $\gamma$-GT to replenish intracellular glutathione on the sinusoidal surface of the liver cells ${ }^{57}$.

We have also observed an increase in GST activity following protein deficiency treatment. Ramdath and Golden $^{58}$ reported a similar increase in malnourished children. Cho et $\mathrm{al}^{59}$ stated that the antioxidant response element (ARE)-binding activity of protein-calorie malnutrition rats gets increased, which in turn results in activation of certain GST mRNAs and a higher GST activity.

The observed normalization of GSH levels and GST activity following $\mathrm{Zn}$ treatment could be because of its property to induce metallothionein (S-rich protein) as a free radical scavenger, or its indirect action in reducing the levels of oxygen reactive species ${ }^{60}$, however the precise mechanism for these actions remains to be elucidated.

In conclusion, the present study highlights the protective role of zinc in maintaining the activities of enzymes involved in oxidative of stress induced in conditions of protein deficiency.

\section{Acknowledgements}

This work was supported by financial grant from IUC-DAE, Kolkata and ICMR, New Delhi. We are al- so thankful to Prof. T. Butz, Fakultät für Physik and Geowissenschaften, Universitdt Leipzig, Leipzig, Germany for helping in zinc analysis.

\section{References}

1. Poluten J, Kapila Jordi C, Lluis A: Nickel -induced hyperglycaemia: the role of insulin and glucagons. Toxicology 1992, 71:181-192.

2. Crogan NL, Pasvogel A: The influence of protein-calorie malnutrition on quality of life in nursing homes. J Gerontol A Biol Sci Med Sci 2003, 58:159-164.

3. Kusal KD, Shbantula D: Alteration of testicular biochemistry during protein restriction in nickel treated rats. Biol Trace Elem Res 1997, 60:243-249.

4. Taylor CG, Potter AJ, Rabinovitch PS: Splenocyte glutathione and CD3-mediated cell proliferation are reduced in mice fed a protein deficient diet. J Nutr 1997, 127:44-50.

5. Keusch GT: The history of nutrition: malnutrition, infection and immunity. J Nutr 2003, 133:336S-340S.

6. Ammigan N, Nair UJ, Bhide SV: Effect of dietary protein on masheri induced drug metabolizing enzymes. Nutr Res 1989, 9:1397-1405.

7. Ramdath DD, Golden MH: Elevated glutathione-s-transferase activity in erythrocytes from malnourished children. Eur $J$ Clin Nutr 1993, 47:658-665.

8. Huang CJ, Fwu ML: Degree of protein deficiency affects the extent of the depression of arttioxidative enzyme activities and the enhancement of tissue lipid peroxidation in rats. $J$ Nutr 1993, 123:803-810.

9. Tat MM, Vural H, Koc A, Kosecik M, Atas A: Altered antioxidant status and increased lipid peroxidation in marasmic children. Pediatr Int 2000, 42:289-292.

10. Darmon N, Pelissier MA, Heyman M, Albrecht R, Desjeux JF: Oxidative stress may contribute to the intestinal dysfunction of weanling rats fed a low protein diet. J Nutt 1993, 123:1068-1075.

11. Tandon A, Dhawan DK, Nagpaul JP: Effect of lithium on hepatic lipid peroxidation and antioxidative enzymes under different dietary protein regimens. J Appl Toxicol 1998, 18:187-190.

12. Deneka SM, Gershoff SN, Fanburg BL: Potentiation of oxygen toxicity in rats dietary protein or amino acids deficiency. $\mathrm{J}$ of Appl. Physiol Resp Envirin Exercise Physiol 1983, 54:147157.

13. Tandon A, Nagpaul JP, Bandhu H, Singh N, Dhawan D: Effect of lithium on hepatic and serum elemental status under different dietary protein regimens. Biol Trace Elem Res 1999, 68:51-62.

14. Squali Houssaini FZ, Foulon T, Payen N, Iraqi MR, Arnaud J, Groslaeinbert P: Plasma fatty acid status in Moroccan children: increased lipid peroxidation and impaired polyunsaturated fatty acid metabolism in protein-calorie malnutrition. Biomed Pharmacother 2001, 55:155-612.

15. Singla PN, Chand P, Kumar A, Kachhawaha JS: Serum, zinc and copper levels in children with protein energy malnutrition. Indian J Pediatr 1996, 63:199-203.

16. Bhaskaram P, Hemalatha P: Zinc status of Indian children. Indian J Med Res 1995, 102:210-215.

17. Babcock AK, Henkin RI: Effects of oral zinc loading on zinc metabolism in human II. In vivo kinetics. Metab Clin Exp 1982, 31:335-347.

18. Srivastava RC, Hasan SK, Gupta J, Gupta S: Protective role of metallothionein in nickel induced oxidative damage. Biochem Mol Biol Int 1993, 30:261-370.

19. Driscoll ER, Bettger WJ: Zinc deficiency in the rat alters the lipid composition of the erythrocyte cell membrane. Triton Shell Lipids 1992, 27:972-977.

20. Boukaiba: A physiological amount of zinc supplementation Effects on nutritional, lipid and thymic status in an elderly population. Am J Clin Nutr 1993, 57:566-572.

21. Dhawan DK, Goel A: Protective role of zinc on rat liver function in long term toxicity induced by carbon tetrachloride. $J$ Trace Elem Exp Med 1994, 7:1-9. 
22. Kau J, Jaswal VM, Nagpaul JP, Mahmood A: Chronic ethanol feeding and microvillus membrane glycosylation in normal and protein-malnourished rat intestine: Nutrition 1992, 8:338342.

23. Lowry OH, Rosebrough NJ, Farr AL, Randall J. Protein measurement with the Folin Phenol reagent. J Biol Chem 1951, 193:265-275.

24. Luck H. Catalase. In: Methods of Enzymatic analysis. (Eds. Bergmeyer, HO, Academic Press, New York., London), 1971; 885-893.

25. Flohe L, Gurzler WA: Assays of glutathione peroxidase. Methods Enzymol. 1984, 105:114-21

26. Williams $\mathrm{CH}$ Jr., Arscott ID: Glutathione reducatse. Methods in Enzymology, Vol. XVII B (SP Colowick and NO Kaplan, Eds., Academic Press, New York), 1971, 503-59.

27. Moron MJ, Dipierre JW, Mannerv KB: Levels of glutathione, glutathione reductase and glutathione-s-transferase activities in rat lung and liver. Biochem Biophys Acta 1979, 582:67-71.

28. Habig WH, Pabst MJ, Jakoby WB: Glutatjhione S-Transferase: The first enzymatic step in mercapturic acid formation. $J$ Biol Chem 1974, 249:7130-7139.

29. Ohokawa H, Oshishi N, Yagi K: Assay for lipid peroxidation in animal tissues by thiobarbituric acid reaction. Anal Biochem 1979, 75:351-358.

30. Wang G, Yu S, Bao C: Effect of different levels of protein intake on metabolism of protein, zinc and copper in rats. Zhonguo Gonggong Weishing Xuebao. 1995, 14:90-93.

31. Bauman PF, Smith TK, Bray TM: The effect of dietary protein and sulfur aminoacids on hepatic glutathione dependent enzyme activities in the rat. Can J Physiol Pharmacol 1988, 66:1048-1052.

32. Yao JZ, Liu JF, Zhang WN, Zhou YJ, Zhu J, Lu JG, Wang $\mathrm{XY}$ : Synthesis, preliminary autigastrelcosis activity and the protective effect on acute liver injury of zinc chloride E4 Yao Xue Xue Bao 2001, 36:188-191.

33. Chen JF, Shi QJ, Zheng SY: Experimental research of protective and therapeutic effects of zinc and vitamin $\mathrm{E}$ on mouse liver radiational damage. Hunan Yi Ke Da Xue Xue Bao 2001, 26:207-210.

34. Martel AC, Reimers EG, Fernández FS, Aleman VC, Martin LG, Moreno FR, Riera AM: Combined effects of ethanol and protein deficiency on hepatic iron, zinc, manganese and copper contents. Alcohol 1992, 9:341348.

35. McClain CJ, Su Le: Zinc deficiency in the alcoholic alcoholism. Winters Press, New York, 1983, 7:5-10.

36. Sandstead HH, Vo-Khactu KP, Solomon N: Trace elements in Human health and disease (Prasad, AS Eds., Vol. 1, Academic Press, New York), 1976, 33-49.

37. Vallee BL, Falchuk KE: The biochemical basis of zinc physiology. Physiol Rev 1993, 73:79-118.

38. Davenport DL Mostardi RA, Richardson DC, Gross KL, Greene, KA, Blair K: Protein-deficient diet alters, serum alkaline phosphatase, bile acids, protein and area nitrogen in dogs. $J$ Nutr 1994, 124:2677S-79S.

39. Yang BS, Ishii H, Satoh A, Kato N: Supplementation of dietary cystine elevates kidney metallothionein in rats by a mechanism involving altered zinc metabolism. J Nutt 1995, 125:1167-1174.

40. Tekeli SK: The study of effects on serum glucose, total lipid, total protein and albumin levels of orally zinc in rats. Trace Elem and Electro 2002, 19:6-10.
41. Gutteridge JM, Halliwell, B: Oxygen radicals and tissue injury. FASEB J 1988, 13:9-19.

42. Shirali P, Teissier E, Marez T, Hildebrand HF, Haguenoer JM: Effect of alpha $\mathrm{Ni}_{3} \mathrm{~S}_{2}$ on arachidonic acid metabolites in cultured human lung cells (L132 cell line). Carcinogenesis 1994, 15:759-762.

43. Dhawan D, Goel A, Gautam CS: Effects of zinc intake on liver enzymes in carbontetrachloride induced liver injury. Med Sci Res 1992, 20:55-6.

44. Chow CK: Interrelationships of cellular antioxidant defense systems. In: Cellular Antioxidant Defense Mechanisms (Chow C.K. Ed) Vol. II pp. 217-237. CRC Press, Boca Raton, 1989.

45. Cadenas: Biochemistry of oxygen toxicity. Am Rev Biochem 1989, 58:79-110.

46. Zhu Z, Kimura M, Itokawa Y: Effect of selenium and protein deficiency on selenium and glutathrione peroxidase in rats. Biol Trace Elem Res 1993, 36:15-23.

47. Ayala A, Gordillo E, Castano A, Lobato MF, Machado A Involvement of diminution of glutathione, produced by deficiency of methionine in the diet, in the elevation of malic enzyme level in rat liver. Biochim Biophys Acta 1991, 1084:48-51.

48. Pelissier MA, Boisset M, Atteba S, Albrecht R: Lipid peroxidation of rat liver microsomes membranes related to a protein deficiency and / or a PCB treatment. Food Addit Contam 1990, 7 (Supl. 1):S172-177.

49. Michiels C, Raes M, Toussaint O, Remacle J: Importance of Seglutathione peroxidase, catalase and $\mathrm{Cu} / \mathrm{Zn}$-SOD for cell survival against oxidative stress. Free Rad Biol Med 1994, 17:235-258.

50. Fridovich I: Superoxide radical and superoxide dismutase. Annu Rev Biochem 1995, 64:97-112.

51. Ram S, Sodhi CP, Mehta S, Vaiphei K, Katyal R, Thakur S, Mehta SK: Protein-energy malnutrition and oxidative injury in growing rats. Hum Exp Toxicol 1996, 15:810-814.

52. Siddiqui MKJ, Mahboob M, Mustafa M: Hepatic and extrahepatic glutathione depletion and glutathione-s-transferase inhibition by monocrotophos and thiol analog. Toxicology 1990, 64:271-279.

53. Meister A: New aspects of glutathione biochemistry and trasport selective alteration of glutathione metabolism. Nutr Rev 1984, 42:397-410.

54. Burk RF: Glutathione dependent protection by rat liver microsomal protein against lipid-peroxidation. Biochem Biophys Acta 1983, 757:21-28.

55. Hum S, Koski KG, Hofet LJ: Varied protein intake alters glutathione metabolism in rats. $J$ Nutr 1992, 122:2010-2018.

56. Taniguchi $\mathrm{M}$ and Cherian MG: Ontogenic changes in hepatic glutathione and metallothionein in rats and the effect of a lowsulphurcontaining diet. Br J Nutr 1990, 63:97-103.

57. Chow CK: Nutritional influence on cellular antioxidant defense systems. Am J Clin Nutr 1979, 32:1066-1081.

58. Ramdath DD, Golden MH: Elevated glutathione-s-transferase activity in erythrocytes from malnourished children. Eur $J$ Clin Nutr 1993, 47:658-665.

59. Cho MK, Kim YG, Lee MG, Kim SG: The effect of cysteine on the altered expression of class alpha and mu glutathione $\mathrm{S}$ transferase genes in the rat liver during protein-calorie malnutrition. Biochim Biophys Acta 2000, 1502:235-246.

60. Seagrave J, Tobey RA, Milderbrand CE: Zinc effects on glutathione metabolism. Relationship to zinc induced protection from alkalylating agents. Biochem Pharmacol 1983, 32:3017-3021. 